This is an electronic reprint of the original article. This reprint may differ from the original in pagination and typographic detail.

Author(s): Taiminen, Heini

Title: How do online communities matter? Comparison between active and non-active participants in an online behavioral weight loss program

Year: $\quad 2016$

Version:

Please cite the original version:

Taiminen, H. (2016). How do online communities matter? Comparison between active and non-active participants in an online behavioral weight loss program. Computers in Human Behavior, 63, 787-795.

https://doi.org/10.1016/j.chb.2016.06.002

All material supplied via JYX is protected by copyright and other intellectual property rights, and duplication or sale of all or part of any of the repository collections is not permitted, except that material may be duplicated by you for your research use or educational purposes in electronic or print form. You must obtain permission for any other use. Electronic or print copies may not be offered, whether for sale or otherwise to anyone who is not an authorised user. 


\section{How do online communities matter? Comparison between active and non-active participants in an online behavioral weight loss program}

\section{Introduction}

The internet and social technologies have provided interesting new platforms to implement different kinds of health-related interventions aiming for behavior change. In health care, information systems have great potential to reduce costs and improve outcomes (Fichman et al., 2011; Kelley et al., 2011; Kolodner et al., 2008). One interesting, cost-effective, and

efficient aspect is to harness social media to support health behavior change. Online communities in social media, often called online support groups (OSGs), are used extensively in giving and receiving social support, such as informational and nurturing support (see, e.g., Ballantine \& Stephenson, 2011; Coursaris \& Liu, 2009; Gray, 2013; Hether et al., 2014; Hwang et al., 2011; Patel et al., 2015). Although social media platforms provide effective ways to participate, it remains unclear what types of benefits participation can provide in health behavior change.

Some studies have yielded modest evidence supporting the effectiveness of social media in health-related behavior change. These studies include a recent systematic literature review of health behavior change interventions (tobacco and alcohol consumption, dietary intake, physical activity, and sedentary behavior) that used social media (Maher et al., 2014); a systematic review and meta-analysis of randomized controlled trials (RCTs) of social media interventions for diet and exercise behavior (Williams et al., 2014); and a systematic review of social media use in chronic disease treatment (Patel et al., 2015). These literature reviews conclude that the RCT studies have rarely reported significant differences in key outcomes (such as weight loss or increased physical activity) between control groups and groups having access to social media elements (Maher et al., 2014; Williams et al., 2014). However, in the 
most studied RCTs, the specific role of social media cannot be tracked, since often the social media component has not been the only component that has been modified in an RCT setting (see Maher et al., 2014; Patel et al., 2015; Williams et al., 2014). For example, in RCT studies evaluating the effect of an online forum, in addition to the availability of the online forum, various digital elements were added such as tailored messages or e-mail feedback (see Gow et al., 2010; Harvey-Berino et al., 2004; Hurling et al., 2007; Morgan et al., 2011; Tate et al., 2006); mobile reminders (Hurling et al., 2007); self-monitoring tools (Tate et al., 2001; Tate et al., 2006); and additional information via websites (van Genugten et al., 2012). More research is needed to clarify the specific role of social media (Hurling et al., 2007).

Furthermore, low participation rates have been a major limitation in studies of interventions related to social media, restricting the interpretation of the results of previous studies (Morgan et al., 2011; Pullen et al., 2008; Rydel et al., 2005; Tate et al., 2006; Webber, et al., 2010; Williams et al., 2014; Womble et al., 2004). In some interventions, the lack of significant differences between the control group and the group that had access to the social media platform may be a result of low utilization of the provided channels (Cavallo et al., 2012), which prevented participants from achieving the expected benefits. Many of the studies do not pay enough attention to the frequency of use of these social media channels in interventions; the channels do exist, but their existence alone does not in itself bring benefits. As Oinas-Kukkonen (2013) has observed, if a system is not used, it is not likely to be very persuasive; therefore, it is not likely to be effective. For that reason, it is important to pay attention to the usage of social media platforms when evaluating their benefits.

Additionally, the differences in social media channels and their designs should be taken into consideration (Fichman et al., 2011). More research at the system-feature level or at the level of categories in systems features, rather than at the level of the whole system (OinasKukkonen, 2013), is needed to better understand and design effective technology-based health 
interventions. As Oh et al. (2013) commented, more research is also required to determine specific social media functions that are more likely to lead to benefits for patients; meaning information about the benefits of such functions could then be disseminated.

For the above reasons, this paper reports on a study of the utilization of two different types of social media platforms (a Facebook-based community and an online forum ${ }^{1}$ based community) in the context of an online behavioral weight loss program. In this observational study, participants of the same online program were divided into three groups based on their utilization of different social media channels in the program, plus a control group of those who did not actively utilize the social media communities provided. Because channel usage was the only differentiator, reliable comparisons among users of each channel type made it possible to relate channel types to users' perceptions of service-related aspects, aspects related to behavioral change, and perceived social support.

\section{Theory}

\subsection{Different types of social media}

Social media is not just one platform, but a collection of platforms that are based on Web 2.0 technology allowing two-way user-to-user interactions. Within these platforms, users are able to create communities. Kaplan and Haenlein (2010) identified six different types of social media platform: collaborative projects (e.g., Wikipedia and OhMyNews); blogs (e.g., textbased blogs, podcasts, and Twitter); content communities (e.g., discussion forums, YouTube); social networking sites (e.g., Facebook and LinkedIn); virtual game worlds (e.g., World of Warcraft); and virtual social worlds (e.g., Second Life and Habbo).

These platforms differ for example based on their level of media richness and the level of self-presentation they provide (Kaplan \& Heinlein, 2010), and also based on the half-life of their information and depth of communication they can convey (Weinberg \& Pehlivan, 2011) 
as well as their usage logic and ease of use. In the context of eHealth services, these networking platforms must be straightforward to use and fit into people's everyday lives to be effective (Hardiker \& Grant, 2011). These differences set different premises for online community interactions within each platform. Next the two often-used social media platforms for OSGs, social networking sites and online discussion forums, are compared.

Social networking sites (e.g., Facebook, Google+, and LinkedIn) are social media channels with high self-presentation (Kaplan \& Haenlein, 2010). This means that users experience each other as real people. It is important to note that people often interact on Facebook with their real names and have profiles that include rich information about the user. As social presence theory states the greater the social presence, the larger the social influence that the partners to communication have on each other's behavior (Short et al., 1976). The communication within these sites is often rich, in terms of the number of options to communicate available within the site (i.e., liking, sharing, posting pictures and videos, rather than just text-based communication). As media richness theory informs us, the richer the medium is, the more effective it is (Daft \& Lengel, 1986). Furthermore, people frequently use social networking sites such as Facebook daily, often browsing their own news feed curated for them and exposing themselves to the communication present without making an effort to log in separately. The platform is also strongly integrated into peoples' everyday lives.

Discussion forums are content communities where the interaction is focused primarily on topics and issues, not on relationship building. Often the communication is limited to textbased communication, which equates to poor media richness. In many cases, users of content communities are not even required to make a personal profile page, and if they do so, such pages might include only basic information, such as the amount of content shared and the date of joining (Kaplan \& Haenlein, 2010), which makes communication rather faceless and anonymous. Compared to social networking sites, the level of self-presentation is lower 
(Kaplan \& Haenlein, 2010). With regard to usage logic and ease of use, discussion forums rarely include similar kinds of news feed features requiring an effort by the user to go to a specific forum to review what is going on.

The main differences between social networking sites and online forums are summarized in Table 1 using Kaplan and Haenlein's (2012) classification of social media channels based on their level of media richness and level of social presence, and also comparing channels from the perspective of their usage logic.

Table 1. Comparison of social networking sites and anonymous online forums

\begin{tabular}{l|l|l} 
& $\begin{array}{l}\text { Social networking sites (such as } \\
\text { Facebook) }\end{array}$ & Online forums/discussion boards \\
\hline $\begin{array}{l}\text { Media } \\
\text { richness }\end{array}$ & $\begin{array}{l}\text { Often offer multiple options to } \\
\text { communicate, such as reading, } \\
\text { commenting, liking, sharing, and posting } \\
\text { pictures, videos, and files. }\end{array}$ & $\begin{array}{l}\text { Communication functions are often limited to } \\
\text { reading and posting verbal communication. }\end{array}$ \\
\hline presence & $\begin{array}{l}\text { Contain a high level of self-presentation } \\
\text { (real profiles). }\end{array}$ & $\begin{array}{l}\text { Contain a low level of self-presentation } \\
\text { (nicknames). }\end{array}$ \\
\hline Usage logic & $\begin{array}{l}\text { Often used on a daily basis (allow push } \\
\text { the user interface is familiar. }\end{array}$ & $\begin{array}{l}\text { Often require a separate log in to the forum or } \\
\text { opening the site where the forum exists, and } \\
\text { user interfaces vary among forums. }\end{array}$ \\
$\begin{array}{l}\text { Exposure to communication is possible } \\
\text { without logging in to the group; the } \\
\text { messages are visible on people's regular } \\
\text { news feeds. }\end{array}$ & $\begin{array}{l}\text { Require that the user go to the forum to have } \\
\text { exposure to the communication within the } \\
\text { group. }\end{array}$ \\
Often strongly integrated into offline lives.
\end{tabular}

\subsection{Usage and role of social media in health behavior change}

The most often-used social media tool in the diet and exercise intervention context is an online forum (or discussion board); blogs and social networking sites are used far less often in 
diet and exercise interventions (Williams et al., 2014). In the case of chronic diseases and social media utilization, Facebook is the most often-used channel, followed by blogs and Twitter (Patel et al., 2015). In addition, Wikipedia and YouTube are sometimes used.

In general, social media platforms devoted to chronic diseases are used to provide support, but they are also used for educational purposes, diagnosis, disease management, and disease moderation (see Patel et al., 2015). Online social networks such as Facebook have been used as additional platforms to motivate users to keep going (see, e.g., Ballantine \& Stephenson, 2011; Cavallo et al., 2012; Herring et al., 2014; Valle et al., 2013), and to allow users to receive and share support (see, e.g., Ballantine \& Stephenson, 2011; Cavallo et al., 2012; Herring et al., 2014; Valle et al., 2013), to provide help with disease moderation (Herring et al., 2014; Napolitano et al., 2013; Turner-McGrievy \& Tate, 2011), and provide a social and competitive context (Foster et al., 2010), or a channel to fully deliver a whole behavior change intervention (Foster et al., 2010). Similar types of roles have been identified for online discussion forums, which have also been used, for example, as platforms to share and receive support (see, e.g., Gow et al., 2010; Hurling et al., 2007; Hwang et al., 2011; Hwang et al., 2014; Tate et al., 2001), and to educate participants (Pullen et al., 2008).

In the context of obesity, positive support-related outcomes of social media usage have been reported (see, e.g., Hwang et al., 2014; Leggatt-Cook et al., 2012; Pagoto et al., 2014; Pullen et al., 2008). In an RCT setting, though, the role of social media cannot be fully traced in current studies, with the exception of a few approximate studies. In one of those RCT studies, Pullen et al. (2008) isolated the effect of a forum-based peer support group by comparing a website-only group to a website plus peer-led support group (Pullen et al., 2008). In that study, the website plus peer-led support group participation seemed to drive better health outcomes related to losing weight, although the size of the sample analyzed (eight participants in both groups) does not make it possible to draw solid conclusions about the role 
of social media use. Brindal et al. (2012) studied web-based intervention for weight loss, comparing a) those who participated in an information-based group (a non-interactive version of the program); b) a supportive group (an interactive site with social support features, an interactive meal planner, and visualizations); and c) a personalized support group (similar to group b but with a personalized meal planner). In Brindal et al.'s study, differences were not found between groups in terms of weight loss; however, participants in the interactive site group differed significantly in terms of liking the site, evaluating the usefulness of the website for supporting their diet, and being willing to recommend the site.

In accordance with social learning theory, spending time in online communities may provide models of positive health-related attitudes and behaviors that facilitate observational learning (Bandura, 1977; 2004). Although it seems that adding social media or an interactive function in the course of an intervention might not lead to increased weight loss, such additions might be related to other factors that indirectly influence desired outcomes related to the service experience (see, e.g., Brindal et al., 2012), health behavior change, or perceived social support.

\section{Material and methods}

\subsection{Data collection and study context}

An online survey was conducted among the participants of one six-week long online behavioral weight loss program. The studied program was specifically directed at overweight people desiring to lose weight by following given diet instructions and doing planned exercises.

In this study context, the participants received slightly modified diet instructions based on healthy eating using basic food ingredients every week. The instructions were delivered 
via the service provider's website, which also offered recipes and instructional videos on workouts, and every week, the company posted an encouraging video to inspire participants to achieve their goals. The website also featured two closed discussion forums for this specific training course where users could participate anonymously (using nicknames). On the first platform, participants could ask questions about diet, exercise, and so forth of the training team. On the second platform, participants could discuss issues, ask questions, and share their thoughts and feelings with each other without a company representative being involved. They were able to start new discussions, comment on running discussions, and, of course, just read messages that others had posted. In addition, one senior participant working with (but not for) the service provider started a closed Facebook community that the participants could join if they wished. There they could post comments, respond to others' comments, upload pictures or videos, share files, indicate approval of others' posts, and follow ongoing conversations in their own Facebook feed. On Facebook, the participants operated under their real names, and their profile includes images of themselves.

An online survey was sent via e-mail to all the participants immediately after the program ended, with reminder messages sent one week after the first message. This resulted in 519 responses, with an effective response rate of $69 \%$ among those who opened the survey link. The sample was representative of the studied population (all participants in this particular six-week training program), but for reasons of confidentiality, the overall number of participants could not be reported. According to the representative of the service provider, the participant profiles also fit well with the average profile of people participating in this type of training program. To encourage participants to complete the survey, five gift vouchers with values of between 20 and 50 euros redeemable at stores unrelated to the service provider were raffled among the respondents.

\subsection{Measures}


A large variety of aspects was selected, related to service experience, behavior change, and perceived social support as the previous literature does not really give solid answers as to how participating in different community channels matters.

\section{Frequency of use}

The scales for measuring the frequency of using these online communities were developed for this research according to the particular features of these channels. The scales were developed following Chung (2014), Hwang et al. (2014), and Men and Tsai (2013). Seven items relating to frequency of use were available to the Facebook users, and three such items were available to the forum users. For each question, the response options on the Likert-type scale were as follows: never (1); once during the six-week period (2); a few times during the six-week period (3); once per week (4); a few times per week (5); daily (6); and several times per day (7).

\section{Aspects related to service experience}

As with previous studies (see Brindal et al., 2012), it was noted that adding interactive elements (of which social media is an example) might lead to a more positive service experience, accordingly, elements were included in the questionnaire to elicit differences in the groups' perceptions of their experiences. In relation to service experience satisfaction, word-of-mouth (WOM) communication, repurchase intention, and general brand attitude were evaluated. Overall satisfaction was measured using the first five of the seven items from Hausman's (2004) study, originally based on a scale proposed by Westbrook and Oliver (1991). Items for measuring WOM communication (one item) and repurchase intention (one item) were adopted from Kim et al. (2008). General brand attitude was evaluated using the four-item brand attitude scale of MacKenzie et al. (1986). 
The success of the behavioral change project was measured in terms of the key outcomes of the program: perceived success, following instructions, perceived behavioral control, intention to carry on, and relative BMI change. To measure perceived success, three items were developed based on the work of Baldwin et al. (2006). One item measured satisfaction with achieving goals: "Given the effort you put into following your weight control plan, how satisfied are you with your progress over the past week?" The measure for following instructions was developed from the example provided by Hether et al. (2014), but in this study, three items evaluated compliance with instructions on different aspects of the training program. The four items used for measuring perceived behavioral control were adopted from Povey et al. (2000). In the same vein, the study of Povey et al. (2000) was the source of items related to intention to continue to live healthily but the current research adds one more specific item, to give a total of four items. In addition, the body mass index (BMI) of the participants was assessed from self-reported data by calculating the weight loss percentage from participants (height, weight at the beginning of the study, and weight at the end). From these data, relative weight change was calculated to make it possible to compare results.

Relative weight change $=(B M I$ at the beginning $-B M I$ at the end $) / B M I$ at the beginning

\section{Perceived social support}

Several studies have positively related social media usage to support-related outcomes (see, e.g., Hwang et al., 2014; Leggatt-Cook et al., 2012; Pagoto et al., 2014; Pullen et al., 2008; Leggatt-Cook et al., 2012). Therefore, in this study, the subjects' perceptions of social support from their online peers were evaluated among the participating groups. Ballantine and Stephenson's (2011) measures were adopted to measure emotional and informational support in the context of this study (eight items measuring emotional support and six items measuring informational support). A scale for measuring instrumental support was adopted from the 
studies of Rieder and Ruderman (2007) and Lin et al. (2015). However, in the present study, the presentation and wording of the questions were revised based on the assumption that a person who feels that he or she can receive instrumental support from peers has had enough support to fill that need. It is important to emphasize that these scales specifically measured the support received by participants from their weight loss group peers, not perceived general social support. Each question was measured using a 7-point Likert scale anchored with strongly disagree (1) and strongly agree (7).

\section{Other variables}

Following the research of Chung (2014), this study obtained information about the participants' age, gender, co-residency (whether they live alone or with someone), and urban or rural residency. Questions about education, race, and the duration of OSG use were excluded because of the context of this study, and questions about employment status, and general activity on social media were put instead.

\subsection{Analysis}

The data were analyzed using SPSS, and AMOS was used to confirm the structural characteristics of each factor. First, the data were split into four different groups based on respondents' frequency of use of the Facebook-based community or online forum-based community.

First, to make sense of the results, the mean for each factor was computed as one value. Before that, each factor was confirmed using AMOS, in which all the factors indicated good fit. The results of this phase are presented in Table 2 .

Table 2. Descriptive statistics 


\begin{tabular}{|c|c|c|c|c|c|}
\hline & Source & $\begin{array}{l}\text { Modification made for original } \\
\text { scale }\end{array}$ & $\begin{array}{l}\text { Number } \\
\text { of items }\end{array}$ & $\begin{array}{l}\text { Squared multiple } \\
\text { correlations } \\
\text { (SMC) }^{\mathrm{a},}\end{array}$ & $\begin{array}{l}\text { Cronbach's } \\
\boldsymbol{\alpha}^{\mathrm{c}}\end{array}$ \\
\hline Satisfaction & Hausman (2004) & - & 5 & all over 0.56 & 0.922 \\
\hline Brand attitude & MacKenzie et al. (1986) & - & 4 & all over 0.7 & 0.254 \\
\hline $\begin{array}{l}\text { Following } \\
\text { instructions }\end{array}$ & Hether et al. (2014) & $\begin{array}{l}\text { Two added items, specific to this } \\
\text { context. }\end{array}$ & 3 & all over 0.73 & 0.832 \\
\hline $\begin{array}{l}\text { Perceived behavioral } \\
\text { control }\end{array}$ & Povey et al. (2000) & $\begin{array}{l}\text { Items } 3 \text { and } 4 \text { were modified to } \\
\text { better fit to the context of this } \\
\text { study. }\end{array}$ & 4 & $\begin{array}{l}\text { items } 1,2 \text { and } 4 \\
\text { over } 0.42 ; \text { item } 3 \\
0.14^{\mathrm{b}}\end{array}$ & 0.094 \\
\hline $\begin{array}{l}\text { Intention to live } \\
\text { healthily }\end{array}$ & Povey et al. (2000) & $\begin{array}{l}\text { Original scale measured healthy } \\
\text { eating intention in the future with } \\
\text { two items. }\end{array}$ & 4 & all items over 0.31 & 0.903 \\
\hline Perceived success & Baldwin et al. (2006) & Two added items. & 3 & all over 0.64 & 0.739 \\
\hline Emotional support & $\begin{array}{l}\text { Ballantine and } \\
\text { Stephenson (2011) }\end{array}$ & $\begin{array}{l}\text { Small modification was made to } \\
\text { better capture the context of this } \\
\text { study. }\end{array}$ & 8 & all over 0.56 & $0.05^{\mathrm{d}}$ \\
\hline $\begin{array}{l}\text { Informational } \\
\text { support }\end{array}$ & $\begin{array}{l}\text { Ballantine and } \\
\text { Stephenson (2011) }\end{array}$ & $\begin{array}{l}\text { Small modification was made to } \\
\text { better capture the context of this } \\
\text { study. }\end{array}$ & 6 & all over 0.67 & 0.292 \\
\hline $\begin{array}{l}\text { Instrumental } \\
\text { support }\end{array}$ & $\begin{array}{l}\text { Rieder and Ruderman } \\
\text { (2007) and Lin et al. } \\
\text { (2015) }\end{array}$ & $\begin{array}{l}\text { The questions were about a } \\
\text { hypothetical situation and not } \\
\text { about actual behavior. }\end{array}$ & 3 & all over 0.42 & 0.196 \\
\hline \multicolumn{6}{|c|}{$\begin{array}{l}\text { aSMC value between } 0.3-0.5 \text { indicates that the item is an adequate measure of the construct. } \\
\text { aSMC value over } 0.5 \text { indicates that the item is a good measure of the construct. } \\
\text { ' } \text { Since good model fit the item was left to the scale. } \\
\text { dicates that the factor model is a good representation of the relationships among the variables } \\
\text { dRMSEA was }<0.05 \text { indicating good fit }\end{array}$} \\
\hline
\end{tabular}

Second, the respondents were classified based on whether they used (took advantage of, or contributed to) each community option actively, meaning at least once per week (response had a value of three or over at least in one question measuring frequency of use for each platform) or did not used a community option actively, meaning the option was used less than once per week, following the categorization scheme of Hwang et al. (2014). Then, the sample was divided into four mutually exclusive groups on the basis of respondents' participating in online platforms. The groups were labeled as follows: 1) non-active users (not participating actively i.e. participated less than once per week, in any community channels); 2) Facebook community users (those who actively, i.e. at least once per week, participated only on Facebook); 3) forum community users (those who actively, i.e. at least once per week, participated only on an online forum); and 4) forum and Facebook community users (those 
who actively, i.e. at least once per week, participated on both a forum and Facebook). The respondents were divided into the four groups as follows: approximately one third belonged to the non-active user group $(n=162,31.2 \%)$; one tenth belonged to the Facebook-only group ( $n=50,9.6 \%)$; one third belonged to the forum-only group $(n=164,31.6 \%)$; and one quarter belonged to the forum and Facebook community user group $(n=143,27.6 \%)$.

The differences among groups were tested with an analysis of variance (ANOVA), and a post-hoc test was conducted using Tukey's test. The groups did not differ from each other statistically for most of the demographic characteristics, but the results show that there were statistically significant differences in all the studied factors.

\section{Results}

\subsection{Demographic profile of the groups}

Most of the respondents were female (94.7\%), lived in an urban area (66\%), and lived with somebody $(85.2 \%)$. The group of those who did not participate in community channels (nonactive users) had the highest mean age $(\bar{x}=38.2)$, differing statistically from those who participated actively in both channels $(\bar{x}=33.4)$, who were significantly younger. In addition, the general social media usage level varied between the groups. Generally, the most active social media users used a Facebook-based community $(\bar{x}=6.4)$ or both a forum and Facebook communities $(\bar{x}=6.4)$, whereas the users who were generally less active on social media used a forum-based community $(\bar{x}=4.8)$ or did not use community channels in general at all $(\bar{x}=$ 4.3). The first two and the latter two groups did not differ from each other significantly (see Table 3). 
Table 3. Basic characteristics of the data

\begin{tabular}{|c|c|c|c|c|c|c|c|c|c|c|c|c|c|c|c|c|c|c|}
\hline & \multicolumn{2}{|l|}{ All } & \multicolumn{2}{|c|}{$\begin{array}{l}\text { G1 Those who did } \\
\text { not participate } \\
\text { actively on } \\
\text { community } \\
\text { channels }\end{array}$} & \multicolumn{2}{|c|}{$\begin{array}{l}\text { G2 Those who } \\
\text { participated } \\
\text { actively only on } \\
\text { Facebook } \\
\text { community }\end{array}$} & \multicolumn{2}{|c|}{$\begin{array}{l}\text { G3 Those who } \\
\text { participated } \\
\text { actively only in } \\
\text { forum } \\
\text { community }\end{array}$} & \multicolumn{2}{|c|}{$\begin{array}{l}\text { G4 Those who } \\
\text { actively } \\
\text { participated on } \\
\text { Facebook and in } \\
\text { forum - } \\
\text { communities }\end{array}$} & \multicolumn{2}{|c|}{ All groups } & \multicolumn{2}{|c|}{$\begin{array}{l}\text { G1 } \\
\text { and } \\
\text { G2 }\end{array}$} & $\begin{array}{l}\text { G1 } \\
\text { and } \\
\text { G4 }\end{array}$ & $\begin{array}{l}\text { G2 } \\
\text { and } \\
\text { G3 }\end{array}$ & $\begin{array}{l}\text { G2 } \\
\text { and } \\
\text { G4 }\end{array}$ & $\begin{array}{l}\text { G3 } \\
\text { and } \\
\text { G4 }\end{array}$ \\
\hline & Mean & SD & Mean & SD & Mean & SD & Mean & SD & Mean & SD & $\begin{array}{l}\text { F } \\
\text { value }^{\mathrm{a}}\end{array}$ & Sig. ${ }^{a}$ & Sig. ${ }^{b}$ & Sig. ${ }^{b}$ & Sig. ${ }^{\text {b }}$ & Sig. ${ }^{b}$ & Sig. & Sig. ${ }^{b}$ \\
\hline Age & 35.8 & 10.7 & 38.2 & 11.5 & 33.9 & 10.1 & 36.0 & 9.8 & 33.4 & 10.4 & 5.8 & $0.001 *$ & 0.059 & 0.232 & $0.001 *$ & 0.611 & 0.995 & 0.154 \\
\hline \multirow{2}{*}{$\begin{array}{l}\text { General } \\
\text { social media } \\
\text { usage }\end{array}$} & 5.3 & 2.3 & 4.3 & 2.5 & 6.4 & 1.2 & 4.8 & 2.5 & 6.4 & 1.1 & 31.7 & $0^{*}$ & $0^{*}$ & 0.211 & $0^{*}$ & $0^{*}$ & 1 & $0^{*}$ \\
\hline & $\begin{array}{l}\text { Female } \\
n(\%)\end{array}$ & $\begin{array}{l}\text { Male } \\
n(\%)\end{array}$ & $\begin{array}{l}\text { Female } \\
n(\%)\end{array}$ & $\begin{array}{l}\text { Male n } \\
(\%)\end{array}$ & $\begin{array}{l}\text { Female } \\
n(\%)\end{array}$ & $\begin{array}{l}\text { Male } \\
n(\%)\end{array}$ & $\begin{array}{l}\text { Female } \\
n(\%)\end{array}$ & $\begin{array}{l}\text { Male } \\
n(\%)\end{array}$ & $\begin{array}{l}\text { Female } \\
n(\%)\end{array}$ & $\begin{array}{l}\text { Male n } \\
(\%)\end{array}$ & & & & & & & & \\
\hline \multirow[t]{2}{*}{ Gender } & $\begin{array}{l}482 \\
(94.7)\end{array}$ & $\begin{array}{l}27 \\
(5.3)\end{array}$ & $336(96)$ & $14(4)$ & $48(98)$ & $1(2)$ & $\begin{array}{l}146 \\
(91,8)\end{array}$ & $13(8)$ & $48(98)$ & $1(4)$ & 2.2 & 0.082 & 0.335 & 0.861 & 0.093 & 0.663 & 1.000 & 0.394 \\
\hline & $\begin{array}{l}\text { Alone } n \\
(\%)\end{array}$ & $\begin{array}{l}\text { With } \\
\text { smb. } n \\
(\%)\end{array}$ & $\begin{array}{l}\text { Alone } n \\
(\%)\end{array}$ & $\begin{array}{l}\text { With } \\
\text { smb. n } \\
(\%)\end{array}$ & $\begin{array}{l}\text { Alone } n \\
\text { (\%) }\end{array}$ & $\begin{array}{l}\text { With } \\
s m b . \\
n(\%)\end{array}$ & $\begin{array}{l}\text { Alone } n \\
(\%)\end{array}$ & $\begin{array}{l}\text { With } \\
\text { smb.n } \\
(\%)\end{array}$ & $\begin{array}{l}\text { Alone } n \\
(\%)\end{array}$ & $\begin{array}{l}\text { With } \\
\text { smb. } n \\
(\%)\end{array}$ & & & & & & & & \\
\hline \multirow[t]{2}{*}{ Lives } & $\begin{array}{l}76 \\
(14.8)\end{array}$ & $\begin{array}{l}436 \\
(85.2)\end{array}$ & $25(15.5)$ & $\begin{array}{l}136 \\
(84.5)\end{array}$ & $8(16,7)$ & $\begin{array}{l}40 \\
(83.3)\end{array}$ & $\begin{array}{l}24 \\
(14.9)\end{array}$ & $\begin{array}{l}137 \\
(85.1)\end{array}$ & $19(13,4)$ & $\begin{array}{l}123 \\
(86.6)\end{array}$ & .141 & 0.935 & 0.997 & 0.999 & 0.954 & 0.991 & 0.946 & 0.982 \\
\hline & $\begin{array}{l}\text { Countr } \\
\text { ysiden } \\
(\%)\end{array}$ & $\begin{array}{l}\text { Rural- } \\
\text { area } n \\
(\%)\end{array}$ & $\begin{array}{l}\text { Country } \\
\text { side } n \\
(\%)\end{array}$ & $\begin{array}{l}\text { Rural- } \\
\text { area } n \\
(\%)\end{array}$ & $\begin{array}{l}\text { Country } \\
\text { side n } \\
(\%)\end{array}$ & $\begin{array}{l}\text { Rural } \\
\text {-area } \\
n(\%)\end{array}$ & $\begin{array}{l}\text { Country } \\
\text { side } n \\
(\%)\end{array}$ & $\begin{array}{l}\text { Rural- } \\
\text { area n } \\
(\%)\end{array}$ & $\begin{array}{l}\text { Country } \\
\text { side } n \\
(\%)\end{array}$ & $\begin{array}{l}\text { Rural- } \\
\text { area } n \\
(\%)\end{array}$ & & & & & & & & \\
\hline Residence & $\begin{array}{l}173 \\
(34)\end{array}$ & $\begin{array}{l}336 \\
(66)\end{array}$ & $62(69.2)$ & $\begin{array}{l}96 \\
(60.8)\end{array}$ & $\begin{array}{l}18 \\
(36.7)\end{array}$ & $\begin{array}{l}31 \\
(63.3)\end{array}$ & $\begin{array}{l}41 \\
(25.5)\end{array}$ & $\begin{array}{l}120 \\
(75.5)\end{array}$ & $52(36.9)$ & $\begin{array}{l}89 \\
(63.1)\end{array}$ & 2.635 & $0.049^{*}$ & 0.988 & $0.046^{*}$ & 0.973 & 0.46 & 1 & $\begin{array}{l}0.155 \\
(39.2)\end{array}$ \\
\hline
\end{tabular}




\subsection{Aspects related to service experience}

Participants who took part actively in both forum and Facebook communities $(\bar{x}=5.3)$ were significantly more satisfied with their service experience than the other groups. In addition, those participating only in an online forum community $(\bar{x}=5.1)$ were significantly more satisfied than those who did not participate actively in communities $(\bar{x}=4.6)$ and those who participated actively only in Facebook community $(\bar{x}=4.9)$. The differences identified in the groups parallel the users' willingness to spread information about their experience (WOM), as well as on their repurchase intentions; however, there are no statistically significant differences among those who participated actively on the different types of community channels. Furthermore, those who participated actively in an online forum community $(\bar{x}=$ 6.4) had the most positive brand attitude, differing significantly from those who did not participate actively in any communities $(\bar{x}=5.8)$ or participated in a Facebook community $(\bar{x}$ $=6.1$ ), but not from those who participated actively both on an online forum and in Facebook communities $(\bar{x}=6.2)$. This indicates that participating actively on community channels, especially online forums might drive positive brand attitude and increase the willingness to share experiences (WOM) and also to purchase the provider's service packages in the future. Increasing the active participation on different online community channels seems to be related with brand-related aspects. (Note that these community channels were not facilitated or hosted by the company owning the brand.) The service experience-related factors of each group are presented in Table 4.

Table 4. Aspects related to the service experience

\begin{tabular}{|c|c|c|c|c|c|c|c|c|c|c|c|c|c|c|c|c|c|}
\hline \multirow{4}{*}{$\begin{array}{l}\text { Satisfac- } \\
\text { tion } \\
\text { WOM }\end{array}$} & \multirow[t]{2}{*}{$\begin{array}{l}\text { All } \\
\text { Groups } \\
\\
\overline{\mathbf{x}} \\
50\end{array}$} & \multicolumn{2}{|c|}{$\begin{array}{l}\text { Group } 1 \\
\text { Non } \\
\text { active }\end{array}$} & \multicolumn{2}{|c|}{$\begin{array}{l}\text { Group } 2 \\
\text { Active } \\
\text { only on } \\
\text { Faceboo } \\
\text { k }\end{array}$} & \multicolumn{2}{|c|}{$\begin{array}{l}\text { Group } 3 \\
\text { Active } \\
\text { only on a } \\
\text { forum }\end{array}$} & \multicolumn{2}{|c|}{$\begin{array}{l}\text { Group } 4 \\
\text { Active on } \\
\text { Faceboo } \\
k \text { and a } \\
\text { forum }\end{array}$} & \multicolumn{2}{|c|}{ All groups } & \multirow[t]{2}{*}{$\begin{array}{l}\text { G1 } \\
\text { and } \\
\text { G2 }\end{array}$} & \multirow[t]{2}{*}{$\begin{array}{l}\text { G1 } \\
\text { and } \\
\text { G3 } \\
\text { Sig. }\end{array}$} & \multirow[t]{2}{*}{$\begin{array}{l}\text { G1 } \\
\text { and } \\
\text { G4 } \\
\\
\text { Sig. }^{b}\end{array}$} & \multirow[t]{2}{*}{$\begin{array}{l}\text { G2 } \\
\text { and } \\
\text { G3 } \\
\text { Sig. }\end{array}$} & \multirow[t]{2}{*}{$\begin{array}{l}\text { G2 } \\
\text { and } \\
\text { G4 } \\
\\
\text { Sig. }^{\text {b }}\end{array}$} & \multirow[t]{2}{*}{$\begin{array}{l}\text { G3 } \\
\text { and } \\
\text { G4 } \\
\\
\text { Sig. }^{\text {b }}\end{array}$} \\
\hline & & $\overline{\mathbf{x}}$ & SD & $\overline{\mathbf{x}}$ & SD & $\overline{\mathbf{x}}$ & SD & $\overline{\mathbf{x}}$ & SD & $\mathbf{F}^{\mathrm{a}}$ & Sig. ${ }^{a}$ & & & & & & \\
\hline & 5.0 & 4.6 & 1.1 & 4.9 & 1 & 5.1 & 0.8 & 5.3 & 0.7 & 13.2 & $0 *$ & 0.223 & $0^{*}$ & $0^{*}$ & 0.748 & 0.08 & 0.19 \\
\hline & 5.6 & 5 & 1.8 & 5.5 & 1.5 & 5.8 & 1.2 & 6 & 1.2 & 12.7 & $0 *$ & 0.202 & $0 *$ & $0^{*}$ & 0.621 & 0.15 & 0.55 \\
\hline
\end{tabular}




\begin{tabular}{|c|c|c|c|c|c|c|c|c|c|c|c|c|c|c|c|c|c|}
\hline $\begin{array}{l}\text { Repurchase } \\
\text { intention }\end{array}$ & 4.8 & 4.3 & 1.8 & 4.8 & 1.6 & 5.1 & 1.6 & 5.2 & 1.6 & 8.8 & $0 *$ & 0.263 & $0 *$ & $0 *$ & 0.76 & 0.45 & 0.88 \\
\hline $\begin{array}{l}\text { Brand } \\
\text { attitude }\end{array}$ & 6.1 & 5.8 & 1.4 & 6.1 & 1 & 6.4 & 0.8 & 6.2 & 1.1 & 8 & $0 *$ & 0.253 & $0 *$ & $0.012^{*}$ & 0.484 & 0.99 & 0.42 \\
\hline
\end{tabular}

\subsection{Aspects related to success in the behavior change project}

Participation on community channels also significantly increased compliance with the instructions given to the participants. Particularly those who actively participated on a forum community $(\bar{x}=5.4)$ or on both a forum and Facebook communities $(\bar{x}=5.4)$ followed the instructions received more precisely than others. Interestingly, the groups did not differ significantly in their relative weight change. The result indicates that channel usage and relative weight change are not directly related to each other.

Furthermore, those who actively participated in a forum community $(\bar{x}=6.1)$ or in both a forum and Facebook communities $(\overline{\mathrm{x}}=6.1)$ reported significantly higher perceived behavioral control than did those who did not participate actively on any community channels $(\bar{x}=5.8)$. In addition, those who participated actively in online communities perceived their ability to live more healthily more strongly $(\overline{\mathrm{x}}=6.5)$ than did those who had not participated in such communities $(\overline{\mathrm{x}}=6.1)$. In addition, the differences between the groups parallel the respondents' intention to live more healthily in the future. The results related to success in the behavior change project are presented in Table 5.

Table 5. Aspects related to success in the behavioral change project

\begin{tabular}{|c|c|c|c|c|c|c|c|c|c|c|c|c|c|c|c|c|c|}
\hline & $\begin{array}{l}\text { All } \\
\text { Groups }\end{array}$ & $\begin{array}{l}\text { Gr } \\
\text { No } \\
\text { act }\end{array}$ & & $\begin{array}{l}\text { Gro } \\
\text { Act } \\
\text { onl } \\
\text { Fac }\end{array}$ & & $\begin{array}{l}\text { Gro } \\
\text { Act } \\
\text { only } \\
\text { fort }\end{array}$ & $\begin{array}{l}\text { p } 3 \\
\text { e } \\
\text { on a } \\
\text { n }\end{array}$ & $\begin{array}{l}\text { Gro } \\
\text { Acti } \\
\text { Face } \\
\text { and }\end{array}$ & $\begin{array}{l}\text { p } 4 \\
\text { e on } \\
\text { oook }\end{array}$ & All & oups & $\begin{array}{l}\text { G1 } \\
\text { and } \\
\text { G2 }\end{array}$ & $\begin{array}{l}\text { G1 } \\
\text { and } \\
\text { G3 }\end{array}$ & $\begin{array}{l}\text { G1 } \\
\text { and } \\
\text { G4 }\end{array}$ & $\begin{array}{l}\text { G2 } \\
\text { and } \\
\text { G3 }\end{array}$ & $\begin{array}{l}\text { G2 } \\
\text { and } \\
\text { G4 }\end{array}$ & $\begin{array}{l}\text { G3 } \\
\text { and } \\
\text { G4 }\end{array}$ \\
\hline & $\overline{\mathbf{x}}$ & $\overline{\mathbf{x}}$ & SD & $\overline{\mathbf{x}}$ & SD & $\overline{\mathbf{x}}$ & SD & $\overline{\mathbf{x}}$ & SD & $F^{a}$ & Sig. ${ }^{a}$ & Sig. ${ }^{b}$ & Sig. ${ }^{b}$ & Sig. ${ }^{b}$ & Sig. ${ }^{b}$ & Sig. ${ }^{b}$ & Sig. ${ }^{b}$ \\
\hline $\begin{array}{l}\text { Perceived } \\
\text { success }\end{array}$ & 5 & 4.5 & 1.9 & 4.6 & 1.4 & 5.3 & 1.4 & 5.3 & 1 & 11 & $0 *$ & 0.967 & $0 *$ & $0 *$ & $0,04^{*}$ & $0,027^{*}$ & 0.994 \\
\hline $\begin{array}{l}\text { Following } \\
\text { instructions }\end{array}$ & 5.2 & 4.6 & 1.8 & 4.9 & 1.5 & 5.4 & 1.4 & 5.6 & 1 & 15 & $0^{*}$ & 0.641 & $0^{*}$ & $0 *$ & 0.071 & $0,014^{*}$ & 0.801 \\
\hline
\end{tabular}




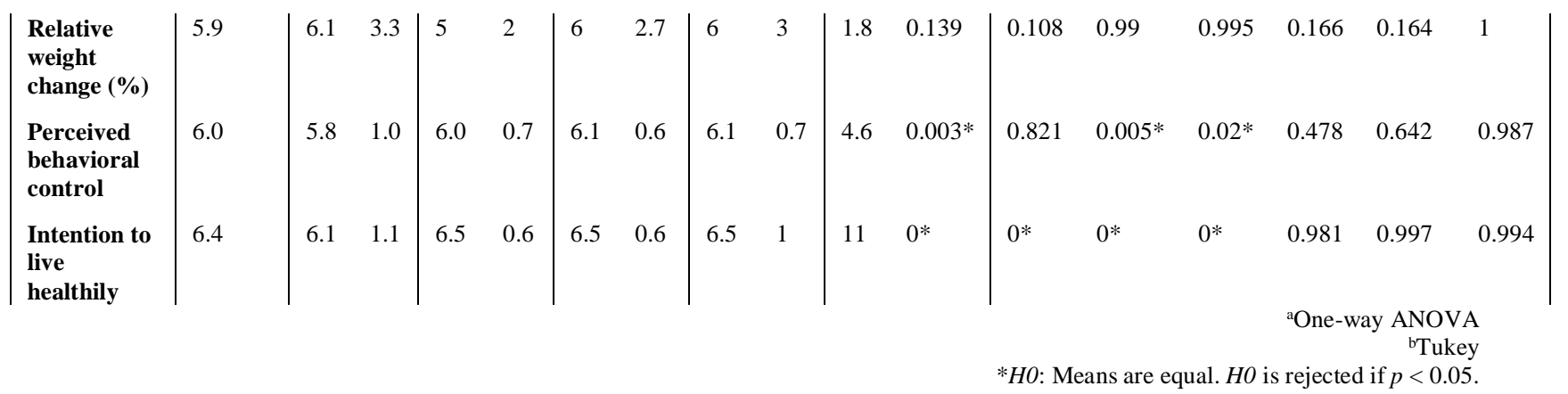

\subsection{Perceived peer social support}

Those who participated in online community channels, especially the Facebook community and both the forum and Facebook communities reported perceiving more peer social support than others. Those who participated actively in the Facebook community $(\bar{x}=5.0)$ or on both a forum and Facebook communities $(\bar{x}=5.3)$ experienced significantly more emotional support than those who participated only in a forum community $(\bar{x}=4.0)$ or did not actively participate in any community channels $(\bar{x}=3.0)$. In the case of informational support, the results are similar, but the users of both a forum and Facebook $(\bar{x}=5.5)$ reported perceiving significantly more informational support than those who used only Facebook $(\bar{x}=4.8)$. In perceived instrumental support, those who participated in a forum $(\bar{x}=2.6)$ and those who did not participate in online community channels at all $(\bar{x}=2.5)$ did not differ from each other, whereas those who participated actively in a Facebook community $(\bar{x}=3.2)$ or in both a forum and Facebook communities $(\bar{x}=3.7)$ did perceive significantly more instrumental support. Results related to perceived peer social support are presented in Table 6 .

Table 6. Perceived peer social support.

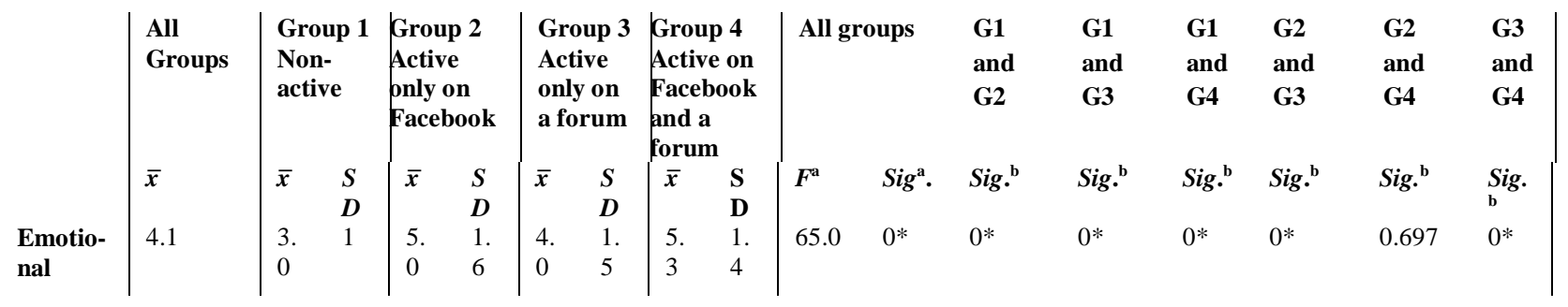




\begin{tabular}{|c|c|c|c|c|c|c|c|c|c|c|c|c|c|c|c|c|c|}
\hline $\begin{array}{l}\text { Informa } \\
\text {-tional }\end{array}$ & 4.3 & $\begin{array}{l}3 . \\
1\end{array}$ & $\begin{array}{l}1 . \\
6\end{array}$ & $\begin{array}{l}4 . \\
8\end{array}$ & $\begin{array}{l}1 . \\
6\end{array}$ & $\begin{array}{l}4 . \\
2\end{array}$ & $\begin{array}{l}1 . \\
5\end{array}$ & $\begin{array}{l}5 . \\
5\end{array}$ & $\begin{array}{l}1 . \\
2\end{array}$ & 68.9 & $0^{*}$ & $0^{*}$ & $0^{*}$ & $0 *$ & $0.049 *$ & $0.041 *$ & $0^{*}$ \\
\hline $\begin{array}{l}\text { Instru- } \\
\text { mental }\end{array}$ & 2.9 & $\begin{array}{l}2 . \\
5\end{array}$ & $\begin{array}{l}1 . \\
5\end{array}$ & $\begin{array}{l}3 . \\
2\end{array}$ & $\begin{array}{l}1 . \\
5\end{array}$ & $\begin{array}{l}2 . \\
6\end{array}$ & $\begin{array}{l}1 . \\
6\end{array}$ & $\begin{array}{l}3 . \\
7\end{array}$ & $\begin{array}{l}1 . \\
6\end{array}$ & 19.9 & $0^{*}$ & $0.016^{*}$ & 0.807 & $0^{*}$ & 0.083 & 0.198 & $0^{*}$ \\
\hline
\end{tabular}

\section{Conclusions}

This paper examined the utilization of two different types of social media platforms (Facebook and an online forum) in an online behavior weight loss program. The study compared the active users of each medium to each other, as well as to program participants who were not active users of these community channels, to respond to the call for research on social media in a health context.

This paper adds insight to the discussion of the specific role of social media in healthrelated interventions (see, e.g., Maher et al., 2014; Patel et al., 2015; Williams et al., 2014). The results of this study show that participating actively on social media channels benefits participants. However, in line with previous findings (see, e.g., Brindal et al., 2012; Maher et al., 2014; Williams et al., 2014), the utilization of community channels seemed to have no impact with regard to key measures such as weight loss. Despite this, active users of community channels seemed to have a stronger intention of carrying on a healthier lifestyle in the future, reported greater perceived success, perceived greater behavior control, and experienced more peer social support. The exposure to community channels might not be related to key outcomes measuring the short-term impact of intervention success such as weight loss; however, the results indicate that differences might be found among these groups over the long term. In addition, those who actively participated in communities and exposed themselves to information and the experiences of other users perceived their service experience significantly more positively than non-active users, mirroring the findings of Brindal et al. (2012) relating to the positive aspects of adding interactive elements to webbased weight loss interventions. Therefore, in addition to health-related outcomes, the results 
suggest that participating in community channels might also have positive brand-related outcomes and play a significant role in the formation of brand experience.

Second, the results of this study highlight the importance of paying attention to active participation on social media channels, which has been a major concern of social media intervention studies (Morgan et al., 2011; Pullen et al., 2008; Rydell et al., 2005; Tate et al., 2006; Webber et al., 2010; Williams et al., 2014; Womble et al., 2004). The results of this study confirm the observation of Cavallo et al. (2012) on the influence of active participation: insignificant differences in previous studies might truly be explained by low utilization of the channels. Studies scrutinizing social media usage should pay greater attention to the channel usage, not just its existence or availability in an intervention scenario.

Third, by examining active participation on different types of online community channels (i.e., those based on Facebook and on online forums), the paper addresses the concerns raised by Fichman et al. (2011) about the need to examine the differences between social media channels. This study also addresses the concerns of Oinas-Kukkonen (2013) about the system-feature level aspects, as the results showed differences in perceptions among participants on different types of social media channel. For example, active participation in the Facebook based community seems to relate to a perception of increased emotional support. This might be related to the richness of a particular branch of social media and the social presence that it drives, suggesting that there really are differences in the effectiveness of behavioral change of various social media channels. Overall, active participation on both channels seems to be the most efficient approach in this context. These results contribute to the discussion of the potential use of social media tools to enhance perceived social support from peers in this type of context, and support the conclusion that social media communities can be used to provide social support (Ballantine \& Stephenson, 2011; Coursaris \& Liu, 2009; Gray, 2013; Hether et al., 2014; Hwang et al. 2011; Patel et al., 2015). 
As for practical implications, it is important to understand the potential of these types of different online communities and to consider ways to encourage overweight people to participate in the types of activities reported at least once per week. Unless overweight people are prompted to become involved with communication in online communities, the potential benefits are unlikely to be achieved. These types of communities seem to be an efficient and cost-effective way to positively influence participants' overall experience. For this reason, adding these types of elements in interventions might benefit both the participants and the service provider. By providing social support, these types of communities are also highly effective at providing encouragement and advice for the participants without using expensive resources. Similarly, active participation in these types of communities might have positive consequences, as people might be welcomed to and have their questions answered in their chosen communities. Even if utilization is not directly visible in key outcomes such as weight loss, it still seems to make participants more satisfied; and that should be reason enough for service providers to adopt these types of solutions.

\section{Limitations and avenues for further research}

As does any study, this study has several limitations that need to be considered in an evaluation of the findings. The study's context of weight management and weight loss influences the results and limits the ability to generalize the results to other contexts. In the future, it could be interesting to conduct similar studies with people who have some other health-related concerns. It is also worth noting that the focus in the study was on closed online communities instead of public health forums, which might have affected the positivity of the experience and trust formation within the communities. In addition, this paper focused only on comparing the groups; in the future, it would be beneficial to test the relationships among different aspects and compare different groups. In addition, it would be valuable to inspect the 
long-term effects of participation on community channels. For example, research might investigate if the differences that are visible between user groups in the long term correlate well with key outcomes, such as weight loss or weight maintenance? Furthermore, it is crucial to understand that people are different and have different motivation for embarking on selfimprovement projects; therefore, some people might need more support than others. In the future, it would be beneficial to evaluate different types of users to see whether there are specific user profiles that would particularly benefit from such types of online groups.

\section{Footnotes:}

${ }^{1}$ In this paper, an online forum is regarded as equivalent to an online discussion board.

\section{References}

Baldwin, A.S., Rothman, A.J., Hertel, A.W., Linde, J.A., Jeffery, R.W., Finch, E.A., \& Lando, H.A. (2006). Specifying the Determinants of the Initiation and Maintenance of Behavior Change: An Examination of Self-Efficacy, Satisfaction, and Smoking Cessation. Health Psychology, 25(5), 626-634.

Ballantine, P.W., \& Stephenson, R.J. (2011). Help me, I'm fat! Social support in online weight loss networks. Journal of Consumer Behavior, 10(6), 332-337.

Bandura, A. (1977). Self-efficacy: Toward a Unifying Theory of Behavioral Change. Psychological Review, 84(2), 191-215.

Bandura, A. (2004). Social cognitive theory for personal and social change by enabling media. In A. Singhal, M.J. Cody, E.M. Rogers \& M. Sabido (Eds.), EntertainmentEducation and Social Change: History, Research, and Practice (pp. 75-96). Mahwah, NJ: Lawrence Erlbaum. 
Brindal, E., Freyne, J., Saunders, I., Berkovsky, S., Smith, G., \& Noakes, M. (2012). Features predicting weight loss in overweight or obese participants in a web-based intervention: Randomized trial. Journal of Medical Internet Research, 14(6).

Cavallo, D.N., Tate, D.F., Ries, A.V., Brown, J.D., Devellis, R.F., \& Ammerman, A.S. (2012). A social media-based physical activity intervention: A randomized controlled trial. American Journal of Preventive Medicine, 43(5), 527-532.

Chung, J.E. (2014). Social networking in online support groups for health: how online social networking benefits patients. Journal of Health Communication, 19(6), 639-659.

Coursaris, C.K., \& Liu, M. (2009). An analysis of social support exchanges in online HIV/AIDS self-help groups. Computers in Human Behavior, 25(4), 911-918.

Daft, R.L., \& Lengel. R.H. (1986). Organizational information requirements, media richness and structural design. Management Science, 32(5), 554-571.

Fichman, R.G., Kohli, R., \& Krishnan, R. (2011). Editorial Overview: The Role of Information Systems in Healthcare: Current Research and Future Trends. Information Systems Research, 22(3), 419-428.

Foster, D., Linehan, C., \& Lawson, S. (2010). Motivating physical activity at work: Using persuasive social media extensions for simple mobile devices. CEUR Workshop Proceedings, 690, 11-14.

van Genugten, L., van Empelen, P., Boon, B., Borsboom, G., Visscher, T., \& Oenema, A. (2012). Results from an online computer-tailored weight management intervention for overweight adults: randomized controlled trial. Journal of Medical Internet Research, 14(2).

Gow R.W., Trace S.E., \& Mazzeo S.E. (2010). Preventing weight gain in first year college students: an online intervention to prevent the "freshman fifteen". Eating Behaviors, 11(1), 33-39. 
Gray, J. (2013). Feeding On the Web: Online Social Support in the Breastfeeding Context. Communication Research Reports, 30(1), 1-11.

Hardiker N.R., \& Grant, M.J. (2011). Factors that influence public engagement with eHealth: a literature review. International Journal of Medical Informatics, 80(1), 1-12.

Harvey-Berino, J., Pintauro, S., Buzzell, P., Casey, G.E. (2004). Effect of internet support on the long-term maintenance of weight loss. Obesity Research, 12(2), 320-329.

Hausman, A. (2004). Modeling the Patient-Physician Service Encounter: Improving Patient Outcomes. Journal of the Academy of Marketing Science, 32(4), 403-417.

Herring, S.J., Cruice, J.F., Bennett, G.G., Davey, A., \& Foster, G.D. (2014). Using Technology to Promote Postpartum Weight Loss in Urban, Low-Income Mothers: A Pilot Randomized Controlled Trial. Journal of Nutrition Education and Behavior, 46(6), $610-615$.

Hether, H.J., Murphy, S.T., \& Valente, T.W. (2014). It's Better to Give Than to Receive: The Role of Social Support, Trust, and Participation on Health-Related Social Networking Sites. Journal of Health Communication, 19(12), 1424-1439.

Hurling, R.., Catt, M., Boni, M.D., Fairley, B.W., Hurst, T. Murray, P., Richardson A., \& Sodhi, J.S. (2007). Using internet and mobile phone technology to deliver an automated physical activity program: randomized controlled trial. Journal of Medical Internet Research, 9(2).

Hwang, K.O., Ottenbacher, A.J., Lucke, J.F., Etchegaray, J.M., Graham, A.L., Thomas, E.J., \& Bernstam, E.V. (2011). Measuring social support for weight loss in an internet weight loss community. Journal of Health Communication, 16(2), 198-211.

Hwang, K.O., Etchegaray, J.M., Sciamanna, C.N., Bernstam, E.V, \& Thomas, E.J. (2014). Structural social support predicts functional social support in an online weight loss 
programme. Health Expectations: An International Journal of Public Participation in Health Care and Health Policy, 17(3), 345-352.

Kaplan, A.M., \& Haenlein, M. (2010). Users of the world, unite! The challenges and opportunities of Social Media. Business Horizons, 53(1), 59-68.

Kelley, H., Chiasson, M., Downey, A., \& Pacaud, D. (2011). The Clinical Impact of eHealth on the Self-Management of Diabetes: A Double Adoption Perspective. Journal of the Association for Information Systems, 12(3), 208-234.

Kim, J.W., Choi, J., Qualls, W., \& Han, K. (2008). It takes a marketplace community to raise brand commitment: the role of online communities. Journal of Marketing Management, 24(1), 409-431.

Kolodner, R.M., Cohn, S.P., \& Friedman, C.P. (2008). Health information technology: Strategic initiatives, real progress. Health Affairs, 27(5), 391-395.

Leggatt-Cook, C. \& Chamberlain, K. (2012). Blogging for weight loss: personal accountability, writing selves, and the weight-loss blogosphere. Sociology of Health \& Illness, 34(7), 963-977.

Lin, T-C., Hsu, J. S-C., Cheng, H-L., \& Chiu, C-M. (2015). Exploring the relationship between receiving and offering online social support: A dual social support model. Information \& Management, 52(3), 371-383.

MacKenzie, S.B., Lutz, R.J. \& Belch, G.E. (1986). The role of attitude towards the ad as a mediator of advertising effectiveness: A test of competing explanations. Journal of Marketing Research, 23(2), 130-143.

Maher, C.A., Lewis, L.K., Ferrar, K., Marshall, S., De Bourdeaudhuij, I., \& Vandelanotte, C. (2014). Are health behavior change interventions that use online social networks effective? A systematic review. Journal of Medical Internet Research, 16(2), 1-17. 
Men, L.R., \& Tsai, W.S. (2012). Beyond liking or following: Understanding public engagement on social networking sites in China. Public Relations Review, 39(1), 13-22.

Morgan P.J., Lubans D.R., Collins, C.E., Warren, J.M., \& Callister, R. (2011). 12-Month outcomes and process evaluation of the SHED-IT RCT: an internet-based weight loss program targeting men. Obesity, 19(1), 142-151.

Napolitano, M., Hayes, S., Bennett, G.G., Ives, A.K., \& Foster, G.D. (2013). Using Facebook and Text Messaging to Deliver a Weight Loss Program to College Students. Obesity, 21(1), 25-31.

Oh, H.J., Lauckner, C., Boehmer, J., Fewins-Bliss, R., \& Li, K. (2013). Facebooking for health: An examination into the solicitation and effects of health-related social support on social networking sites. Computers in Human Behavior, 29(5), 2072-2080.

Oinas-Kukkonen, H. (2013). A foundation for the study of behavior change support systems. Personal and Ubiquitous Computing, 17(6), 1223-1235.

Pagoto, S., Schneider, K.L., Evans, M., Waring, M.E., Appelhans, B., Busch, A.M., Whited, M.C., Thind, H., \& Ziedonis, M. (2014). Tweeting it off: characteristics of adults who tweet about a weight loss attempt. Journal of American Medical Information Association, 21(6), 1032-1037.

Patel, R., Chang, T., Greysen, S. R., \& Chopra, V. (2015). Social Media Use in Chronic Disease: A Systematic Review and Novel Taxonomy. The American Journal of Medicine, 123(12), 1335-1350.

Povey, R., Conner, M., Sparks, P., James, R., \& Shepherd, R. (2000). The theory of planned behaviour and healthy eating: Examining additive and moderating effects of social influence variables. Psychology \& Health, 14(6), 991-1006. 
Pullen, C.H., Hageman, P.A., Boeckner, L., Walker, S.N., \& Oberdofer, M.K. (2008). Feasibility of Internet-delivered weight loss interventions among rural women ages 5069. Journal Geriatric Physical Therapy, 31(3), 105-112.

Rieder, S., \& Ruderman, A. (2007). The development and validation of the weight management support inventory. Eating Behaviors, 8(1), 39-47.

Rydell, S.A., French, S.A., Fulkerson, J.A., Neumark-Sztainer, D., Gerlach, A.F., Story, M., \& Christopherson, K.K. (2005). Use of a web-based component of a nutrition and physical activity behavioral intervention with girl scouts. Journal of American Dietetic Association, 105(9), 1447-1450.

Short, J.A., Williams, E., \& Christie, B. (1976). The social psychology of Telecommunications. New York: John Short.

Tate, D.F., Jackvony, E.H., \& Wing, R.R. (2006). A randomized trial comparing human email counseling, computer-automated tailored counseling, and no counseling in an Internet weight loss program. Archives of Internal Medicine, 166(15), 1620-1625.

Tate, D.F., Wing, R.R., \& Winett, R.A. (2001). Using Internet technology to deliver a behavioral weight loss program. JAMA, 285(9), 1172-1177.

Turner-McGrievy, G., \& Tate, D. (2011). Tweets, apps, and pods: results of the 6-month mobile pounds off digitally (Mobile POD) randomized weight-loss intervention among adults. Journal of Medical Internet Research, 13(4).

Valle, C.G., Tate, D.F., Mayer, D.K., Allicock, M., \& Cai, J. (2013). A randomized trial of a Facebook-based physical activity intervention for young adult cancer survivors. Journal of Cancer Survivorship, 7(3), 355-368.

Webber, K.H., Tate, D.F., Ward, D.S., \& Bowling, J.M. (2010). Motivation and Its Relationship to Adherence to Self-monitoring and Weight Loss in a 16-week Internet 
Behavioral Weight Loss Intervention. Journal of Nutrition Education and Behavior, 42(3), 161-167.

Weinberg, B.D., \& Pehlivan, E. (2011). Social spending: Managing the social media mix. Business Horizons, 54(3), 275-282.

Westbrook, R.A. \& Richard L.O. (1991). The Dimensionality of Consumption Emotion Patterns and Consumer Satisfaction? Journal of Consumer Research, 18 (1), 84-91.

Williams, G., Hamm, M.P., Shulhan, J., Vandermeer, B., \& Hartling, L. (2014). Social media interventions for diet and exercise behaviors: a systematic review and meta-analysis of randomized controlled trials. BMJ Open, 4(2), 1-16.

Womble, L.G., Wadden, T.A., McGuckin, B.G., Sargent, S.L., Rothman, R.A., \& Krauthamer-Ewing, E.S. (2004). A randomized controlled trial of a commercial internet weight loss program. Obesity Research, 12(6), 1011-1018. 